OPEN ACCESS

Edited by:

Susanna Hofmann,

Helmholtz Zentrum München,

Germany

Reviewed by:

Ya-Xiong Tao,

Auburn University, United States

Andrew W. Taylor,

Boston University, United States

${ }^{*}$ Correspondence:

Caterina Lonat

caterina.Ionati@gmail.com;

caterina.lonati@policlinico.mi.it

${ }^{\dagger}$ Emeritus

Specialty section: This article was submitted to

Translational Endocrinology,

a section of the journal

Frontiers in Endocrinology

Received: 03 June 2020 Accepted: 10 November 2020 Published: 10 December 2020

Citation:

Lonati C, Gatti S and Catania A (2020) Activation of Melanocortin Receptors as a Potential Strategy to Reduce Local and Systemic Reactions Induced by Respiratory Viruses.

Front. Endocrinol. 11:569241. doi: 10.3389/fendo.2020.569241

\section{Activation of Melanocortin Receptors as a Potential Strategy to Reduce Local and Systemic Reactions Induced by Respiratory Viruses}

\author{
Caterina Lonati $^{*}$, Stefano Gatti and Anna Catania ${ }^{\dagger}$ \\ Center for Preclinical Research, Fondazione IRCCS Ca' Granda Ospedale Maggiore Policlinico, Milan, Italy
}

The clinical hallmarks of infections caused by critical respiratory viruses consist of pneumonia, which can progress to acute lung injury (ALI), and systemic manifestations including hypercoagulopathy, vascular dysfunction, and endotheliitis. The disease outcome largely depends on the immune response produced by the host. The biomolecular mechanisms underlying certain dire consequences of the infection partly arise from an aberrant production of inflammatory molecules, an event denoted as "cytokine storm". Therefore, in addition to antiviral therapies, molecules able to prevent the injury caused by cytokine excess are under investigation. In this perspective, taking advantage of melanocortin peptides and their receptors, components of an endogenous modulatory system that exerts marked anti-inflammatory and immunomodulatory influences, could be an effective therapeutic strategy to control disease evolution. Exploiting the melanocortin system using natural or synthetic ligands can form a realistic basis to counteract certain deleterious effects of respiratory virus infections. The central and peripheral protective actions exerted following melanocortin receptor activation could allow dampening the harmful events that trigger the cytokine storm and endothelial dysfunction while sustaining the beneficial signals required to elicit repair mechanisms. The long standing evidence for melanocortin safety encourages this approach.

Keywords: respiratory viruses, SARS-CoV-2, acute lung injury, cytokine storm, endothelial dysfunction, melanocortin receptors, adenocorticotropin, alpha melanocyte stimulating hormone

\section{INTRODUCTION}

The present pandemic caused by Severe Acute Respiratory Syndrome (SARS)-Coronavirus (CoV)-2 follows outbreaks of other highly pathogenic respiratory viruses that emerged over the past two decades, namely SARS-CoV-1, Middle East respiratory syndrome (MERS)-CoV, and influenza A virus (IAV) H5N1, H1N1, and H7N9.

Clinical hallmarks of severe diseases are pneumonia with marked leukocyte infiltration into the lungs, diffuse alveolar damage (DAD), hyaline membrane formation, and edema (1-4). Pulmonary disease can progress to acute lung injury (ALI), acute respiratory distress syndrome (ARDS), and, in the most severe cases, to fibrosis (5). In addition, systemic manifestations are a major component of the clinical picture. Among these, endotheliitis with lymphocyte infiltration into vessel walls of the 
lung, heart, liver, and kidney (3, 6-8), deranged coagulation $(2,7$, 9-11), and lymphopenia $(4,7,12-14)$ significantly contribute to disease deterioration. There is also evidence for a viral spreading into the central nervous system (CNS) $(7,15,16)$.

The bio-molecular mechanisms underlying clinical pathology partly arise from an aberrant release of inflammatory molecules, an event denoted as "cytokine storm". Therefore, in addition to antiviral therapies, molecules able to prevent the consequences of the cytokine storm are under investigation (1719). Use of corticosteroids was initially controversial due to the immunodepressive potential side effect $(10,14,20-23)$, but their administration is now recommended in selected patients (24). In this perspective, taking advantage of melanocortin peptides and their receptors, components of an endogenous modulatory system, could be an effective and safe therapeutic strategy.

Melanocortins exert marked anti-inflammatory and immunomodulatory influences. Physiological role and effectiveness in treatment of acute, chronic, and systemic inflammatory disorders are well-documented (25-28). Exploiting the melanocortin system could form a realistic basis to counteract certain deleterious effects of respiratory viruses not only for the present but also for possible future pandemics.

\section{PATHOLOGICAL CONSEQUENCES OF VIRUS/HOST INTERACTIONS}

The outcome of CoVs and IAVs-induced disease largely depends on the immune response mounted by the host in response to infection (29-32). The term "cytokine storm" was firstly used to denote a hypercytokinemic state observed in H5N1-infected patients (33). Lung inflammation appears to be the primary "driver" (1-4) triggering excessive systemic production of interferons (IFN), interleukins (IL), chemokines, colony stimulating factors (CSF), and tumor necrosis factors (TNF) $(19,29,30)$. There is now compelling evidence that the cytokine storm significantly contributes to both pulmonary and systemic damage associated with respiratory viral infections $(19,29,30$, 34, 35).

Cytokine storm arises from a virus-induced transient impairment of the physiological antiviral response. The inhibitory effects exerted by CoVs and IAVs on the host immunity are mediated by common mechanisms $(14,29,36)$. Indeed, virus-encoded non-structural proteins are able to prevent immune recognition and IFN-dependent antiviral responses $(19,29,31,32,37-39)$. Besides inhibitory effects, the virus also triggers host inflammatory signals $(31,39)$ through both activation of the nuclear factor (NF)- $\kappa$ B and inflammasome formation $(40,41)$. The initial deficiency of the host immune response allows rapid viral replication and spreading in pulmonary cells. At later stages, deranged activation of the host immunity causes aberrant pulmonary secretion of IL-1ß, TNF- $\alpha$, IL-6, IL-8, MCP-1, MIP-1 $\alpha$, Granulocyte macrophage (GM)-CSF, and Granulocyte (G)-CSF as well as massive recruitment of monocytes/macrophages and neutrophils into the lungs $(14,30-32,36-38,42)$.
When locally-produced inflammatory mediators reach the circulation, the clinical picture turns into systemic inflammation mainly due to activation of endothelial cells (43). Increased expression of adhesion molecules mediates leukocyteendothelial adhesion leading to massive immune cell migration from the blood circulation into the extravascular connective tissue (34). Sustained inflammatory activation of endothelial cells can result in endothelial dysfunction (8) marked by exposure of tissue factor, aberrant release of Von Willebrand factor multimers, and decreased production of endogenous anticoagulants such as tissue factor pathway inhibitor (TFPI) and antithrombin (44). Hypercytokinemia likewise activates the hepatic acute phase response (34). In addition, increased blood concentration of CSFs stimulates the hematopoietic system to release both leukocytes and platelets in the circulation (34). These biological events further boost production of proinflammatory molecules contributing to amplify inflammation. At later stages, high TNF- $\alpha$ concentration induces leukocyte apoptosis, while sustained vascular inflammation elicits endothelial cell death (8). Apoptosis of cells of the respiratory tract and extra-pulmonary tissues is also directly activated by viral proteins $(14,31,45,46)$.

Unbalanced immune responses give rise to many of the pathologic hallmarks observed in respiratory virus-induced disease $(5,14)$. Apoptosis of epithelial and endothelial cells compromises alveolar-epithelial barrier leading to gas exchange impairment and fluid accumulation (30). Cytokine-induced uncontrolled epithelial cell replication, aberrant matrix remodeling, and fibrosis deposition perturb parenchyma architecture with further deterioration of respiratory function. Systemic manifestations are likewise dire components of the picture. Endothelial dysfunction significantly affects the physiological regulation of coagulation, shifting vascular equilibrium towards vasoconstriction, hypercoagulability, and immunothrombosis $(9,11)$. In addition, endotheliitis and consequent vascular leakage mediate translocation of inflammatory molecules as well as recruitment of activated neutrophils and cytotoxic $\mathrm{T}$ cells into peripheral tissue. Therefore, microvascular endothelial dysfunction, widespread immunothrombosis, and diffuse endothelial injury are significant contributing factors in development of tissue injury in extra-pulmonary sites $(29,30,35,43)$. Endothelial cell damage is likewise associated with unbalanced vasoactive molecule production leading to impaired blood pressure control. CD4+ and CD8+ T-cell lymphopenia is likely consequent to both virusrelated direct effects (32) and hypercytokinemia-dependent induction of leukocyte death $(4,7,14,30)$. Finally, enhanced expression of IL-1 and/or other cytokines within the CNS could participate in $\mathrm{T}$ cell exhaustion and natural killer and $\mathrm{B}$ cell suppression observed in COVID-19 (32), leading to development of systemic immunosuppression (47).

This being said, it is important to mention that cytokines also contribute to the biological events required for a successful resolution of infection, including extracellular matrix remodeling and tissue repair (19). Therefore, their production should be modulated but not suppressed. In this view there is a 
clear therapeutic challenge aimed at reducing inflammation without canceling its defensive properties. Indeed, a balanced control of the deleterious virus/host interactions, is crucial to reduce damage and promote resolution; this strategy should complement direct anti-viral procedures.

\section{THE MELANOCORTIN SYSTEM: A POTENT ENDOGENOUS MODULATORY PATHWAY}

\section{Melanocortin Peptides and Their Receptors}

Melanocortins are a family of endogenous peptides produced by CNS and peripheral cells $(25,48,49)$. These peptides derive from post-translational processing of the precursor proopiomelanocortin (POMC) and include the adrenocorticotropic hormone (ACTH) and the melanotropins, $\alpha, \beta$, and $\gamma$-melanocyte-stimulating hormone (MSH).

Although $\alpha$-MSH was initially described as a melanogenic hormone and activity of ACTH was confined to its steroidogenetic effect, it is now well established that melanocortins exert multiple actions on the host physiology. Indeed, over four decades, research has demonstrated that melanocortins have the remarkable ability to restore normal pathways when a certain stimulus perturbs the host homeostasis. Heterogeneous stimuli such as pathogens or their components, ischemia/reperfusion (I/R) injury, or irritants elicit production of melanocortin peptides that, in turn, act to restore equilibrium $(25,49,50)$. Blockade of the natural peptides increases the expression of proinflammatory mediators in the blood, lungs, and liver of endotoxemic mice (51). These observations suggest that when endogenous production is not sufficient to face the challenge, supplementary administration could reach the target.

Melanocortin effects are exerted through recognition of five melanocortin receptors (MCRs) that are broadly distributed in peripheral cells and in brain regions. MCRs are G-protein-coupled receptors associated with adenylyl cyclase and mediate their effects primarily by activating the cAMP-PKA-CREB-dependent signaling pathway but also through activation of mitogenactivated-protein-kinase (MAPK), calcium-inositol triphosphatePI3K, and JAK-STAT pathways $(25,52-54)$. With the exception of the MC2R, which is selectively activated by ACTH, the other MCR subtypes, MC1R, MC3R, MC4R, and MC5R, are recognized by all the natural melanocortins, although with different affinity (55). MC1R is widely expressed in body cells including fibroblasts, neutrophils, monocytes, $\mathrm{B}$ and $\mathrm{T}$ lymphocytes, dendritic cells, alveolar macrophages, glial cells, epithelial cells, and endothelial cells $(25,56-59)$. Binding affinity of endogenous agonists for this receptor is $\alpha-\mathrm{MSH}=\mathrm{ACTH}>\beta-\mathrm{MSH}<\gamma-\mathrm{MSH}$ (55). A large number of in vitro and in vivo studies demonstrate a primary role of MC1R in immunomodulation $(25,48,49)$ as well as in regulation of endothelial cell function $(57,59)$. Of note, mice bearing a nonfunctional MC1R ( $\mathrm{Mc1r} \mathrm{r}^{\mathrm{e} / \mathrm{e}}$ ) show exacerbated inflammatory responses relative to wild-type animals (60) and selective MC1R silencing in macrophages is associated with loss of $\alpha$-MSHmediated suppression of inflammation in vitro (61). Unlike the other MCRs, MC2R exclusively binds to ACTH that selectively induces glucocorticoid production in the adrenal cortex. MC3R is expressed in hypothalamus cells, macrophages, monocytes, dendritic cells, CD4+ T cells, and B lymphocytes and its binding ability to natural melanocortins is $\gamma$-MSH $>\mathrm{ACTH}=\alpha$-MSH $=\beta$ MSH (55). MC3R activation appears to be associated with broad modulation of inflammation in response to acute proinflammatory stimuli (62). MC4R $[\alpha-\mathrm{MSH}=\mathrm{ACTH}>\beta-\mathrm{MSH}>\gamma$ $\mathrm{MSH}$ (55),] is mainly expressed in the CNS and participates in immunodulation through activation of the cholinergic antiinflammatory pathway (63). MC5R is widely expressed in both the CNS and in peripheral tissues, including the lung, kidney, lymph nodes, bone marrow, thymus, and immune competent cells such as B and T lymphocytes, mast cells, and antigen presenting cells (APC) $(53,64)$. Recent evidence suggests that MC5R is deeply involved in regulation of immune reactions and inflammatory responses $(53,65)$. Natural melanocortin order of potency in activating this receptor is: $\alpha-\mathrm{MSH}>\mathrm{ACTH}=\beta-\mathrm{MSH}>>\gamma$ MSH (55).

\section{Synthetic Ligands of MCRs}

Development of synthetic derivatives of melanocortins may allow a better exploiting of the remarkable properties of the natural peptides due to their enhanced chemical stability, resistance to enzymatic degradation, and, for certain of them, more selective receptor recognition (66). A significant breakthrough in this approach was the synthesis of the $\alpha$-MSH analog Nle4,DPhe7- $\alpha$-MSH (NDP- $\alpha$-MSH) marked by prolonged and increased biological activity compared to the endogenous peptide (67). NDP- $\alpha$-MSH (afamelanotide) is clinically used to prevent phototoxicity in erythropoietic protoporphyria and could represent an excellent candidate for other melanocortin-based therapies. Additional $\alpha$-MSH analogs include AP214 (modimelanotide) (68) and STY39 (69) that show higher affinity for MC1R/MC3R and for MC1R/MC5R, respectively. Of particular relevance with regard to clinical use, ACTH-related sequences form a solid basis for MCR-based effective therapies. Indeed, the extra-adrenal effects of ACTH are definitely recognized and these molecules have already been used to treat human inflammatory disorders (70-72).

Selective ligands for individual MCR subtypes are likewise being designed (66), including BMS-470539 (MC1R agonist) (73), [D-Trp8]- $\gamma$-MSH (MC3R) (74), RO27-3225 (MC4R) (75), PG-901 (MC5R) (54), and the N-terminally "capped" tetrapeptide 3,3,3-triphenylpropionyl-His-D-Phe-Arg-Trp-NH (2) (MC5R) (76).

\section{Protective Effects of Melanocortins in Systemic Inflammation and Secondary Organ Damage}

Activation of the melanocortin system with natural or synthetic ligands exerts beneficial effects in acute, chronic, and systemic inflammatory disorders $(25-27,48,49,77)$. Moreover, different clinical studies have investigated efficacy 
of ACTH and NDP- $\alpha$-MSH therapies in systemic inflammatory diseases, including ARDS, rheumatoid arthritis, multiple sclerosis (MS), lupus erythematosus (SLE), kidney diseases, and nephrotic syndromes (70-72).

Table 1 reports the beneficial effects exerted by melanocortins in preclinical models of systemic inflammatory diseases, including sepsis, MODS, I/R injury, hemorrhage shock, and vasculitis.

The marked protection in systemic inflammation was demonstrated by studies conducted in rabbits (50) and mice (51, 77-79). NDP- $\alpha$-MSH administration in murine MODS not only increases survival rate but also reduces pulmonary leukocyte infiltration, vascular congestion, and interstitial edema (80). In a porcine model of systemic inflammatory response syndrome, treatment with the $\alpha$-MSH analog AP214 prevented the LPSinduced increase in pulmonary pressure (81). $\alpha$-MSH or STY39 administration in mice with endotoxemia is associated with increased concentration and mRNA pulmonary expression of TFPI (82).

In a model of renal I/R injury $\alpha$-MSH administration prevented activation of NF- $k$ B and AP-1 in the lungs and reduced the expression of stress response genes, intracellular adhesion molecule (ICAM)-1, and TNF- $\alpha$ (83). In addition, $\alpha$-MSH significantly decreased leukocyte infiltration and lung edema.

Treatment with NDP- $\alpha$-MSH or with the selective MC4 agonists RO27-3225 and PG-931 leads to restoration of cardiovascular and respiratory functions, improved survival, and reduced circulating free radicals in a rat model of severe hemorrhagic shock (84). Moreover, RO27-3225 prevents the hemorrhage-induced immunopathological changes in peripheral organs. Treatment with RO27-3225 normalizes hemogasanalysis parameters after hemorrhagic challenge (85).

Injury to vascular endothelium significantly contributes to convert a local inflammation into a systemic disease. In this perspective, the observation that $\alpha$-MSH administration to endothelial cell challenged with pro-inflammatory stimuli is associated with reduced adhesion molecule expression $(56,87)$ and leukocyte adhesion $(56,87)$ has particular relevance. Further, melanocortin treatment reduced endothelial cell damage and barrier permeability in an in vitro model of blood-brain barrier inflammation (59). With regard to in vivo studies, $\mathrm{Mclr}^{\mathrm{e} / \mathrm{e}}$ mice exposed to high-sodium diet or LPS challenge show increased susceptibility to inflammation-dependent vascular dysfunction (57). In leukocytoclastic vasculitis in mice, $\alpha$-MSH significantly suppresses vascular damage and hemorrhage by inhibiting the early LPS-induced expression of E-selectin and VCAM-1 (86, 87). Activation of MC1R was associated with inhibition of cell adhesion/emigration and reduced tissue expression of CXCL1 and CCL2 in a murine model of vascular inflammation induced by I/R injury (88).

\section{Protective Effects of Melanocortins in Primary Inflammatory Disorders of the Lung} Pulmonary cells express both $\operatorname{MC1R}(89,90)$ and $\operatorname{MC} 3 R(89,91)$. Expression of MC1R mRNA was documented in rat native lungs and a significant up-regulation of this receptor was observed in lungs subjected to ex vivo perfusion (92). As the procedure involves removal of non-resident cells from the lungs, this observation documents that $\mathrm{MC} 1 \mathrm{R}$ is expressed by pulmonary tissue and is further induced during I/R injury.

In in vitro studies, $\alpha$-MSH suppressed IL-1-induced PGE production by fetal human lung fibroblasts (93) and prevented LPS-induced activation of NF- $k \mathrm{~B}$ in human pulmonary epithelial cells (94). The inhibitory effect is mediated by preservation of the $\mathrm{IkB} \alpha$ protein (94). Similarly, $\gamma-\mathrm{MSH}$ treatment suppresses NF- $k \mathrm{~B}$ signaling and exerts several protective effects in a human epithelial cell line challenged with different inflammatory stimuli (91).

The effectiveness of melanocortin treatment in control of primary lung inflammatory diseases is well documented (Table 2): this property could be very beneficial in the protection of organs that are a primary target of respiratory viruses.

In a preclinical model of ARDS based on intratracheal infusion of endotoxin, treatment with $\alpha-\mathrm{MSH}$ was associated with reduced leukocyte count in BAL fluids (77). Similar salutary effects were observed in mice treated with $\alpha$-MSH or a synthetic MC3R agonist after LPS administration (89). In an ARDS model based on induction of hemorrhagic shock followed by intratracheal LPS administration, $\alpha$-MSH-treated rats showed reduced leukocyte infiltration and endothelial cell apoptosis (95). In LPS-induced ALI in mice, MC1R activation with the selective agonist BMS-470539 was associated with improved pulmonary edema, reduced inflammation and neutrophil infiltration (96).

Experiments based on intratracheal instillation of bleomycin are particularly interesting in that this model is widely used to reproduce human ALI and fibroproliferative disorders. A research based on bleomycin instillation in rats, showed that NDP- $\alpha$-MSH administration markedly improves the clinical and molecular picture of ALI (97). In particular, NDP- $\alpha$-MSH treatment was associated with a significant reduction of interstitial edema. At a molecular level, melanocortin treatment prevented bleomycininduced increase in plasma $\mathrm{NO}$ concentration and modulated the expression of genes involved in stress response, inflammation, fluid homeostasis, and fibrosis development. Consistent with the observations that endogenous $\alpha$-MSH participates in responses to host challenge, bleomycin caused a significant increase in circulating $\alpha$-MSH relative to controls. The synthetic $\alpha$-MSH analog STY39 (98), increased survival and improved the lung edema index in the bleomycin model. An interesting observation in this research is that STY39, in addition to inflammation, prevents bleomycin-induced pulmonary expression of pro-fibrotic factors and improves MMP-1/ TIMP-1 mRNAs ratio.

A protective influence of melanocortins on altered cytokine production was likewise documented in a mouse model of allergic airway inflammation (90). Endogenous production of $\alpha$-MSH in BAL after airway allergen challenge was observed. Treatment with $\alpha$-MSH provided further benefit, including reduction in $\mathrm{BAL}$ eosinophils and a decrease in serum allergen-specific IgE, IL-4, and IL-5. Lower concentration of BAL eosinophils and lymphocytes was likewise reported by Getting and coworkers in allergic mice treated with [D-TRP8]$\gamma$-MSH (89). 
TABLE 1 | Protective effects exerted by melanocortin treatment in preclinical models of systemic inflammation and secondary organ damage.

\begin{tabular}{|c|c|c|c|c|c|}
\hline MCR & Compound & Experimental model & $\begin{array}{l}\text { Melanocortin } \\
\text { treatment }\end{array}$ & Melanocortin effect & Ref. \\
\hline
\end{tabular}

\section{Systemic inflammation \\ MC1R, MC3R, $\alpha-\mathrm{MSH}$ MC4R, MC5R}

\begin{tabular}{|c|c|c|}
\hline & $\begin{array}{l}\text { AP214 } \\
\alpha \text {-MSH, STY39 }\end{array}$ & $\begin{array}{l}\text { pig endotoxemia (LPS i.v.); cardiovascular } \\
\text { monitoring from } 20 \text { to } 180 \text { min } \\
\text { mouse, LPS i.p. + D-galactosamine; blood } \\
\text { collection at time intervals, lung biopsy at } 8 \mathrm{~h}\end{array}$ \\
\hline MC3R & $\gamma 2-\mathrm{MSH}$ & $\begin{array}{l}\text { mouse peritonitis (monosodium urate crystals i.p.); } \\
\text { peritoneal lavage at } 4 \text { and } 6 \mathrm{~h}\end{array}$ \\
\hline \multicolumn{3}{|l|}{ I/R injury } \\
\hline $\begin{array}{l}\text { MC1R, MC3R, } \\
\text { MC4R, MC5R }\end{array}$ & $\mathrm{NDP}-\alpha-\mathrm{MSH}$ & $\begin{array}{l}\text { mouse bilateral renal I/R ( } 40 \text { min ischemia }+48 \text { or } \\
24 \mathrm{~h} \text { reperfusion); lung histology at } 4 \mathrm{~h} \text { after } \\
\text { ischemia, lung biopsy at } 0,5,4 \text {, and } 8 \mathrm{~h} \text { after } \\
\text { ischemia }\end{array}$ \\
\hline
\end{tabular}

Hemorrhagic shock

MC1R, MC3R, NDP- $\alpha-M S H$

MC4R, MC5R

MC4R RO27-3225,

PG-931

$\mathrm{RO} 27-3225$

\section{Vasculitis}

MC1R, MC3R, $\quad \alpha-\mathrm{MSH}$

MC4R, MC5R

MC1R rabbit, LPS i.p.; blood collection and body mice septic shock (cecal ligation and puncture); survival at 12 and $24 \mathrm{~h}$ mouse, LPS i.p.; blood collection at 1 and $6 \mathrm{~h}$, liver and lung biopsy at $6 \mathrm{~h}$

mouse peritonitis (monosodium urate crystals i.p.); peritoneal lavage at 4 and $6 \mathrm{~h}$

mouse peritonitis (zymosan i.p or monosodium

mouse, LPS i.p. + zymosan i.p. after 6 d; lung biopsy and histology at $7 \mathrm{~d}$, survival at $16 \mathrm{~d}$ temperature assessment at 0,1 , and $3 \mathrm{~h}$

rat, acute hemorrhagic shock; lung histology at 25 min and at $24 \mathrm{~h}$, survival at $24 \mathrm{~h}$

rat, acute hemorrhagic shock; lung histology at 25 min and $24 \mathrm{~h}$, survival at $24 \mathrm{~h}$

rat, acute hemorrhagic shock; hemogasanalysis at 5, 15, and $60 \mathrm{~min}$

mouse leukocytoclastic vasculitis (s.c LPS priming + i.p LPS after $24 \mathrm{~h}$ ); ear histology at $24 \mathrm{~h}$ after LPS priming and at 2, 3, 5, $6 \mathrm{~h}$ after LPS mouse leukocytoclastic vasculitis (s.c. LPS priming + i.p. LPS after $24 \mathrm{~h}$ ); ear histology at 2 , 3, 5, 6 h after LPS

BMS-470539 mouse vasculitis (35 min mesenteric ischemia + urate crystals i.p.); peritoneal lavage at 4 and $6 \mathrm{~h}$ i.v. immediately before $\quad \downarrow$ fever LPS administration

i.p. at 0 and $3 \mathrm{~h}$

i.c.v. 15 min before LPS inflammatory challenge

s.c. 30 min before inflammatory challenge

i.p. daily from 0 to $16 \mathrm{~d}$

i.v. at $\mathrm{Oh}$

i.p. at 1, 2 or $3 \mathrm{~h}$

following LPS

administration

s.c. 30 min before inflammatory challenge fluids fluids s.c. 30 min before

improved survival rate

$\downarrow$ plasma TNF- $\alpha$ and nitrate

$\downarrow$ iNOS activity and iNOS mRNA in the

lungs and liver

$\downarrow$ lung myeloperoxidase activity

$\downarrow$ neutrophil migration

$\downarrow \mathbb{I L}-1 \beta$ and $\mathrm{CXCL}-1$ in peritoneal lavage

$\downarrow$ neutrophil migration

$\downarrow \mathbb{I L}-1 \beta$ and CXCL-1 in peritoneal lavage

i.v. immediately before $\quad$ lung edema

clamp removal and at $8 \downarrow$ leukocyte infiltration

and $16 \mathrm{~h}$ post ischemia $\downarrow$ TNF- $\alpha$ and ICAM- 1 mRNAs in the lungs

$\downarrow$ lung myeloperoxidase activity

$\downarrow$ IkB $\alpha$, p38, and c-Jun phosphorylation in

the lung tissue

$\downarrow N F-k B$ and AP-1 DNA-binding activity in the lung tissue 90 min reperfusion); intravital microscopy, mesentery tissue biopsy i.v. 5 min after termination of bleeding

i.v. 5 min after termination of bleeding

i.v. 5 min after termination of bleeding

improved survival rate

improved cardiovascular parameters $\downarrow$ blood free radicals improved survival rate improved cardiovascular parameters $\downarrow$ histological damage in the lungs $\downarrow$ blood free radicals improved $\mathrm{pH}, \mathrm{pO}_{2}, \mathrm{pCO}_{2}, \mathrm{HCO}_{3^{-}}, \mathrm{BE}$, $\mathrm{SO}_{2}$, and lactate

i.p. at $3 \mathrm{~h}$ after LPS priming

i.p. at $3 \mathrm{~h}$ after LPS priming

i.v. before ischemia $\downarrow$ vascular hemorrhage score $\downarrow$ E-selectin and VCAM-1-positive vessels

$\downarrow$ vascular hemorrhage score $\downarrow$ E-selectin and VCAM-1-positive vessels

$\downarrow$ leukocyte adhesion and migration $\downarrow$ CXCL1 and CCL2 mesenteric tissue expression

BE, base excess; CXCL-1, chemokine (C-X-C motif) ligand 1; d, day; $h$, hour; $H_{C O}{ }_{3}^{-}$, bicarbonate; ICAM-1, intercellular adhesion molecule 1; IL-1 $\beta$, interleukin-1 $\beta$; IL-10, interleukin-10; $I k B \alpha$, nuclear factor of kappa light polypeptide gene enhancer in B-cells inhibitor, alpha; iNOS, inducible nitric oxide synthase; i.p., intraperitoneal; I/R, ischemia/reperfusion; i.v., intravenous; LPS, lipopolysaccharide; min, minutes; $\mathrm{pO}_{2}$, partial pressure of oxygen; $\mathrm{DCO}_{2}$, partial pressure of carbon dioxide; s.c., subcutaneous; SO ${ }_{2}$, oxygen saturation; TNF- $\alpha$, tumor necrosis factor $\alpha$; TFPI, tissue factor protein inhibitor; VCAM-1, Vascular cell adhesion protein. 
TABLE 2 | Protective effects exerted by melanocortin treatment in preclinical models of primary pulmonary inflammation.

\begin{tabular}{|c|c|c|c|c|c|}
\hline MCR & Compound & Experimental model & $\begin{array}{l}\text { Melanocortin } \\
\text { treatment }\end{array}$ & Melanocortin effect & Ref. \\
\hline \multicolumn{6}{|l|}{ ALI/ARDS } \\
\hline MC1R, & $\alpha-\mathrm{MSH}$ & rat, LPS i.t.; BAL at $6 \mathrm{~h}$ & i.p. at 0,2 , and $4 \mathrm{~h}$ & $\downarrow \mathrm{BAL}$ WBCs & $(77)$ \\
\hline $\begin{array}{l}\text { MC3R, } \\
\text { MC4R, }\end{array}$ & & $\begin{array}{l}\text { rat ARDS (acute hemorrhagic shock + LPS i.t after } 3 \mathrm{~h} \text { ); } \\
\text { lung histology at } 9 \mathrm{~h} \text { post LPS }\end{array}$ & $\begin{array}{l}\text { i.v. at } 0,3 \text {, and } 6 \mathrm{~h} \text { after } \\
\text { LPS administration }\end{array}$ & $\begin{array}{l}\downarrow \text { infiltration of inflammatory cells into alveoli } \\
\downarrow \text { apoptosis of pulmonary endothelial cells }\end{array}$ & $(95)$ \\
\hline MC5R & & mouse, LPS i.n.; BAL at $4 \mathrm{~h}$ & $\begin{array}{l}\text { i.p. } 1 \mathrm{~h} \text { before LPS } \\
\text { administration }\end{array}$ & $\begin{array}{l}\downarrow \text { BAL neutrophils } \\
\downarrow \text { BAL TNF- } \alpha\end{array}$ & (89) \\
\hline MC1R & BMS-470539 & mouse, LPS i.t.; BAL and lung biopsy at $18 \mathrm{~h}$ & $\begin{array}{l}\text { S.C. } 1 \mathrm{~h} \text { before LPS } \\
\text { administration }\end{array}$ & $\begin{array}{l}\downarrow \text { lung W/D ratio } \\
\downarrow \text { BAL leukocytes and PMNs } \\
\downarrow \text { BAL TNF- } \alpha \\
\downarrow \text { lung myeloperoxidase activity }\end{array}$ & $(96)$ \\
\hline MC3R & [D-TRP8]- $\gamma-\mathrm{MSH}$ & mouse, LPS i.n.; BAL at $4 \mathrm{~h}$ & $\begin{array}{l}\text { i.p. } 1 \mathrm{~h} \text { before LPS } \\
\text { administration }\end{array}$ & $\downarrow$ BAL neutrophils; $\downarrow$ BAL TNF- $\alpha$ & $(89)$ \\
\hline \multicolumn{6}{|c|}{ ALI and fibroproliferative disorder } \\
\hline $\begin{array}{l}\text { MC1R, } \\
\text { MC3R, } \\
\text { MC4R, } \\
\text { MC5R }\end{array}$ & NDP- $\alpha-M S H$ & $\begin{array}{l}\text { rat, bleomycin i.t.; blood collection and lung biopsy at } 8 \\
\text { and } 24 \mathrm{~h} \text {, lung W/D at } 24 \mathrm{~h}\end{array}$ & $\begin{array}{l}\text { i.p. immediately before } \\
\text { bleomycin instillation } \\
\text { and at } 12 \mathrm{~h}\end{array}$ & $\begin{array}{l}\downarrow \text { lung W/D ratio } \\
\downarrow \text { expression of genes involved in stress } \\
\text { response, fluid homeostasis, inflammation, } \\
\text { fibrosis }\end{array}$ & $(97)$ \\
\hline & STY39 & $\begin{array}{l}\text { mouse, bleomycin i.t.; daily monitoring, lung index at } 7 \\
\text { and } 14 \mathrm{~d} \text {, BAL at } 7 \mathrm{~d} \text {, lung biopsy at } 9 \mathrm{~d} \text {, lung histology } \\
\text { at } 14 \mathrm{~d}\end{array}$ & $\begin{array}{l}\text { i.p. from } 1 \text { to } 14 \mathrm{~d} \text { after } \\
\text { bleomycin instillation }\end{array}$ & $\begin{array}{l}\downarrow \text { plasma nitrate } \\
\text { improved survival rate } \\
\text { improved cyanosis, tachypnea } \\
\downarrow \text { BAL TNF- } \alpha \text {, IL-6, MIP- } 2 \text {, and TGF- } \beta 1 \\
\downarrow \text { BAL macrophages, neutrophils, and } \\
\text { lymphocytes } \\
\downarrow \text { type I and III procollagen pulmonary } \\
\text { expression } \\
\text { improved MMP-1/TIMP- } 1 \text { mRNA } \\
\text { pulmonary ratio } \\
\downarrow \text { hydroxyproline and myofibroblast } \\
\text { proliferation in the lung tissue }\end{array}$ & (98) \\
\hline \multicolumn{6}{|c|}{ Airway allergic inflammation } \\
\hline $\begin{array}{l}\text { MC1R, } \\
\text { MC3R, } \\
\text { MC4R, } \\
\text { MC5R }\end{array}$ & $\alpha$-MSH & $\begin{array}{l}\text { mouse OVA-induced allergic inflammation (i.p allergic } \\
\text { sensitization at 1,14, and } 21 \mathrm{~d} \text {; aerosol challenge at } 26 \\
\text { and } 27 \mathrm{~d} \text { ); BAL and histology at } 48 \mathrm{~h}\end{array}$ & $\begin{array}{l}\text { i.v. } 30 \text { min before each } \\
\text { sensitization and each } \\
\text { allergen challenge }\end{array}$ & $\begin{array}{l}\downarrow \text { perivascular inflammation } \\
\downarrow \text { peribronchial inflammatory cell infiltrate } \\
\downarrow \text { BAL eosinophils } \\
\downarrow \text { BAL IL-4, IL-13 and } \uparrow \text { IL-10 } \\
\downarrow \text { blood allergen specific IgE }\end{array}$ & $(90)$ \\
\hline MC3R & [D-TRP8]- $\gamma-\mathrm{MSH}$ & $\begin{array}{l}\text { mouse OVA-induced allergic inflammation (i.p. allergic } \\
\text { sensitization at } 0 \text { and } 7 \mathrm{~d} \text {, aerosol challenge at 14, 15, } \\
\text { and } 16 \mathrm{~d} \text { ); BAL at } 24 \mathrm{~h}\end{array}$ & $\begin{array}{l}\text { i.p. } 5 \text { min before each } \\
\text { allergen challenge }\end{array}$ & $\downarrow$ BAL eosinophils and lymphocytes & (89) \\
\hline
\end{tabular}

BAL, bronchoalveolar lavage; d, days; h, hour; IL-4, interleukin-4; IL-6, interleukin 6; IL-10, interleukin-10; IL-13, interleukin-13; i.n., intranasal; i.p., intraperitoneal; i.t., intratracheal; i.v., intravenous; LPS, lipopolysaccharide; min, minutes; MIP-2, macrophage inflammatory protein 2; MMP-1, matrix metalloproteinase 1; OVA, ovoalbumin; PMNs, polymorphonuclear leukocytes; TGF- $\beta 1$, transforming growth factor $\beta 1$; TIMP-1, metallopeptidase inhibitor 1 ; TNF- $\alpha$, tumor necrosis factor $\alpha$; WBC, white blood cells; W/D, wet-to-dry.

\section{Main Protective Pathways Influenced by Melanocortins}

The anti-inflammatory effects of melanocortins are mainly exerted through PKA-mediated prevention of $\operatorname{I\kappa B} \alpha$ degradation and consequent inhibition of the NF- $k B$ signaling in leukocytes $(48,99)$, endothelial cells $(56,59,87)$, and other peripheral cells $(48,94)$. As NF- $k$ B induces the expression of hundreds of genes relevant to inflammation including cytokines, cytokine receptors, chemokines, growth factors, and adhesion molecules, its modulation enables a wide-range regulation of inflammatory responses.

Besides the direct antiphlogistic effects, melanocortins have the peculiar feature to stimulate pro-resolving endogenous circuits $(68,70,100-102)$. In fact, MCR activation is associated with induction of the expression of inhibitors of inflammation and resolutive factors, including IL-10 (103), IL-1 receptorassociated kinase (IRAK)-M (104), suppressor of cytokine signaling (Socs) 1 and $3(101,102), \operatorname{IkB} \alpha(102)$, cyclooxygenase (COX) 2 (102), Chemokine (C-C motif) ligand (CCL) 20 (101, 102), Interleukin 1 receptor antagonist (IL-1ra) $(101,102)$, Dual specificity phosphatase 1 (DUSP1) (105), and IL-1 receptor-like 2 (IL-1rl2) (105). MCR-induced resolving activities likewise include pro-efferocytic effects mediating clearance of apoptotic neutrophils (68).

Moreover, melanocortin peptides can activate immune regulatory mechanisms through induction of $\mathrm{T}$ cell differentiation toward a tolerogenic phenotype (106). In particular, Taylor and coworkers reported $\alpha$-MSH-induced Treg 
cells are CD25+CD4+ and express CTLA4, CD44, CD62L, and latency-associated peptide (LAP) (65). Activation of regulatory activity in effector T cells and APCs was documented in a model of ocular inflammatory disease $(64,65,106,107)$. The modulatory effect on immunity could represent an additional mechanism through which melanocortin peptides promote resolution of inflammation (106).

There is increasing evidence that the diverse immunomodulating effects of melanocortins are carried out through specific MCR targeting. In fact, while resolution of inflammation is mainly achieved through activation of $\operatorname{MC} 1 \mathrm{R}(25,48,49,61)$ and $\operatorname{MC} 3 R(62,78)$, immune regulation appears to be mediated by MC5R (64, 65, 108). As an instance, among the receptors expressed by macrophages, MC1R $(61)$ and $\operatorname{MC} 3 R(68,78)$ are involved in inflammatory response inhibition, whereas MC5R engagement promotes monocyte differentiation toward either myeloid suppressor cell or tolerogenic APCs with subsequent reduction of effector $\mathrm{T}$ cell activation (109).

A peculiar effect of melanocortin peptides consists of indirect influences exerted on peripheral cells through stimulation of MC3R/MC4R within the brain and activation of descending anti-inflammatory neural pathways $(25,48,49,110)$. Lipton and colleagues showed that $\alpha$-MSH given centrally inhibits inflammation in the skin through activation of adrenergic pathways $(110,111)$. A further protective mechanism is based on MC4R signaling and subsequent stimulation of the cholinergic anti-inflammatory pathway (63) that inhibits inflammation in tissue macrophages and lymphoid organs.

Of note, due to its unique peptide sequence, ACTH elicits MC2R-mediated steroidogenesis in the adrenal gland. Therefore, in addition to the protective influences exerted through activation of the other MCRs, ACTH induces glucocorticoid production (70). This additional effect can provide a remarkable clinical advantage as glucocorticoids and melanocortins exert distinct effects as immune modulators (112). Consequently, ACTH can provide combined beneficial effects based on two different pathways. In fact, glucocorticoids can be exploited to induce a general suppression of immune cell activity, inhibit proinflammatory mediator release, promote leukocyte apoptosis, and prevent cell recruitment into damaged tissue. On the other hand, melanocortin peptides, including $\mathrm{ACTH}$, are able to modulate rather than dampen the release of inflammatory mediators, elicit production of resolutive factors, induce leukocyte differentiation towards protective phenotype, and exert a considerable anti-microbial activity $(113,114)$. The distinctive features of glucocorticoids- and melanocortinsbased therapies are particularly manifest in the treatment of ocular inflammatory disorders in which $\alpha$-MSH administration not only suppresses eye inflammation, but also induces immune tolerance and promotes retinal cell survival (115).

Finally, another potentially beneficial effect exerted by melanocortins is protection against apoptotic cell death. This action was observed in pulmonary vascular endothelial cells in a model of ARDS (95), in macrophages exposed to serum starvation in vitro (116), and in a rat model of prolonged myocardial I/R (117).

\section{DISCUSSION: EXPLOITING MELANOCORTIN PATHWAYS TO COUNTERACT RESPIRATORY VIRUS- INDUCED DETRIMENTAL EVENTS}

As stated above, respiratory viruses can alter inflammatory reactions built up by the host to combat the infection. In this scenario, a potentially beneficial cytokine production can turn into a dysregulated harmful event that eventually contributes to development of the severe clinical manifestations observed in CoVs and IAVs-induced diseases. Therefore, modulation of the host aberrant inflammatory responses appears as crucial as controlling viral replication to prevent disease progression.

Melanocortins could reinforce endogenous signals providing protection versus respiratory virus-induced detrimental events. In particular, disruption of the dire and self-amplificating vicious-cycle triggered by mediator release/leukocyte recruitment can significantly reduce pulmonary tissue damage. Through modulation of NF- $k$ B signaling, melanocortin peptides do not influence a single inflammatory mediator but they rather exert control on the whole inflammatory cascade. This effect could be of key importance during respiratory virus infection. Evidence obtained in SARS-CoV-1-infected mice clearly demonstrated that chemical blockade of NF- $k$ B improves lung pathology, reduces inflammation, and increases survival (40). Moreover, melanocortin-induced expression of negative regulators of inflammation as well as the activation of immune regulation mechanisms can counteract pro-inflammatory signals and trigger repair mechanisms crucial to restore homeostasis.

The possibility to induce glucocorticoid production is another peculiar feature inherent in therapeutic activation of melanocortin pathways. Availability of ligands with different affinities to MCRs provides the unique opportunity to either take advantage of or avoid adrenal stimulation, depending on the specific patient clinical situation. In fact, similar to steroid treatment, overproduction of endogenous cortisol can be associated with adverse side effects including increased susceptibility to infections, hypertension, diabetes mellitus, electrolyte disturbances, gastric ulceration, and impaired wound healing (118). On the other hand, based on the most recent guidelines on the use corticosteroid-based therapy in COVID-19, severe and critical patients could significantly benefit from glucocorticoid production (24). Therefore, the use of ACTH requires a preventive assessment to determine the balance between benefits and harms of enhancing corticosteroids (118). Further, it is important to consider that ACTH-induced steroidogenesis produces glucocorticoid plasma concentrations that could be insufficient when high dose steroid therapy is needed (115). Conversely, $\alpha$-MSH and its analogs can be safely administered when adrenal stimulation should be avoided.

In addition to immunomodulation, melanocortin treatment could ameliorate pulmonary edema and fibrosis. Of note, experiments in rodent liver fibrosis demonstrated that melanocortin therapy not only can prevent the biological events leading to fibrosis development but it can also reverse 
established fibrosis and exert a collagenolytic effect (119). Melanocortin-mediated inhibition of pulmonary endothelial cell apoptosis could likewise contribute to preserve alveolarepithelial barrier integrity. Moreover, pharmacological activation of MCRs can exert a protective effect against endothelial inflammation and aberrant activation of coagulation cascades that substantially contribute to disease progression in respiratory virus infections.

Finally, targeting melanocortin system allows exploiting the beneficial effects exerted by the cholinergic anti-inflammatory pathway on systemic inflammation and deranged coagulation (120). In addition, the central neurogenic influences of melanocortins and their effects on descending anti-inflammatory neural pathways could be of paramount importance in view of a potential immunosuppression elicited by virus-induced inflammatory mediator release within the CNS (121).

Therefore, the central and peripheral protective actions exerted following MCR activation could collectively allow dampening the harmful events that trigger the cytokine storm and endothelial dysfunction while sustaining the beneficial signals required to elicit resolution and repair mechanisms.

\section{REFERENCES}

1. Xu Z, Shi L, Wang Y, Zhang J, Huang L, Zhang C, et al. Pathological findings of COVID-19 associated with acute respiratory distress syndrome. Lancet Respir Med (2020) 8(4):420-2. doi: 10.1016/S2213-2600(20)30076-X

2. Ng DL, Al Hosani F, Keating MK, Gerber SI, Jones TL, Metcalfe MG, et al. Clinicopathologic, immunohistochemical, and ultrastructural findings of a fatal case of middle east respiratory syndrome coronavirus infection in the United Arab Emirates, April 2014. Am J Pathol (2016) 186(3):652-8. doi: 10.1016/j.ajpath.2015.10.024

3. Ding Y, Wang H, Shen H, Li Z, Geng J, Han H, et al. The clinical pathology of severe acute respiratory syndrome (SARS): A report from China. J Pathol (2003) 200(3):282-9. doi: 10.1002/path.1440

4. Bautista E. Clinical Aspects of Pandemic 2009 Influenza. N Engl J Med (2010) 362(18):1708-19. doi: 10.1056/NEJMra1000449

5. Shah RD, Wunderink RG. Viral Pneumonia and Acute Respiratory Distress Syndrome. Clin Chest Med (2017) 38(1):113-25. doi: 10.1016/j.ccm.2016.11.013

6. Miyazawa M. Immunopathogenesis of SARS-CoV-2-induced pneumonia: lessons from influenza virus infection. Inflamm Regen (2020) 40:39. doi: 10.1186/s41232-020-00148-1

7. Hui DSC. Review of clinical symptoms and spectrum in humans with influenza A/H5N1 infection. Respirology (2008) 13 Suppl 1:S10-3. doi: 10.1111/j.1440-1843.2008.01247.x

8. Varga Z, Flammer AJ, Steiger P, Haberecker M, Andermatt R, Zinkernagel AS, et al. Endothelial cell infection and endotheliitis in COVID-19. Lancet (2020) 395(10234):1417-8. doi: 10.1016/S0140-6736(20)30937-5

9. Panigada M, Bottino N, Tagliabue P, Grasselli G, Novembrino C, Chantarangkul V, et al. Hypercoagulability of COVID-19 patients in Intensive Care Unit. A Report of Thromboelastography Findings and other Parameters of Hemostasis. J Thromb Haemost (2020) 18(7):173842. doi: $10.1111 /$ jth. 14850

10. Assiri A, Al-Tawfiq JA, Al-Rabeeah AA, Al-Rabiah FA, Al-Hajjar S, AlBarrak A, et al. Epidemiological, demographic, and clinical characteristics of 47 cases of Middle East respiratory syndrome coronavirus disease from Saudi Arabia: A descriptive study. Lancet Infect Dis (2013) 13(9):752-61. doi: 10.1016/S1473-3099(13)70204-4

11. Yang Y, Tang H. Aberrant coagulation causes a hyper-inflammatory response in severe influenza pneumonia. Cell Mol Immunol (2016) 13 (4):432-42. doi: $10.1038 / \mathrm{cmi} .2016 .1$

12. Tan L, Wang Q, Zhang D, Ding J, Huang Q, Tang Y-Q, et al. Lymphopenia predicts disease severity of COVID-19: a descriptive and

\section{CONCLUDING REMARKS}

Enhancing endogenous protective responses to viral infection while inhibiting harmful signals is a key approach to prevent disease progression to a critical life-threatening state, particularly in the absence of specific antiviral drugs. We deem that translational use of melanocortin molecules could be an exploitable strategy in this setting. The key to the unique beneficial modulatory effects induced by melanocortins resides in their capacity to reduce the aberrant responses to infection without impairing the host defense mechanisms. Despite several overlapping influences, this represents a major distinction relative to the other potent, endogenous anti-inflammatory system formed by glucocorticoids. Capacity to take advantage of a protective endogenous system, deeply explored over the years, could help to face present and future emergencies marked by severe pathogen/host interactions.

\section{AUTHOR CONTRIBUTIONS}

All authors listed have made a substantial, direct, and intellectual contribution to the work and approved it for publication.

predictive study. Signal Transduct Target Ther (2020) 5(1):33 doi: 10.1038/s41392-020-0148-4

13. Chan JFW, Yuan S, Kok KH, To KKW, Chu H, Yang J, et al. A familial cluster of pneumonia associated with the 2019 novel coronavirus indicating person-to-person transmission: a study of a family cluster. Lancet (2020) 395 (10223):514-23. doi: 10.1016/S0140-6736(20)30154-9

14. Hendrickson CM, Matthay MA. Viral pathogens and acute lung injury: Investigations inspired by the SARS epidemic and the $2009 \mathrm{H} 1 \mathrm{~N} 1$ influenza pandemic. Semin Respir Crit Care Med (2013) 34(4):475-86. doi: 10.1055/s0033-1351122

15. Yashavantha Rao HC, Jayabaskaran C. The emergence of a novel coronavirus (SARS-CoV-2) disease and their neuroinvasive propensity may affect in COVID-19 patients. J Med Virol (2020) 92(7):786-90. doi: $10.1002 / j m v .25918$

16. Liu J, Zheng X, Tong Q, Li W, Wang B, Sutter K, et al. Overlapping and discrete aspects of the pathology and pathogenesis of the emerging human pathogenic coronaviruses SARS-CoV, MERS-CoV, and 2019-nCoV. J Med Virol (2020) 92(5):491-4. doi: 10.1002/jmv.25709

17. Dong L, Hu S, Gao J. Discovering drugs to treat coronavirus disease 2019 (COVID-19). Drug Discov Ther (2020) 14(1):58-60. doi: 10.5582/ddt.2020.01012

18. Zumla A, Chan JFW, Azhar EI, Hui DSC, Yuen KY. Coronaviruses-drug discovery and therapeutic options. Nat Rev Drug Discov (2016) 15:327-47. doi: $10.1038 / \mathrm{nrd} .2015 .37$

19. Guo X zhi J, Thomas PG. New fronts emerge in the influenza cytokine storm. Semin Immunopathol (2017) 39(5):541-50. doi: 10.1007/s00281-017-0636-y

20. Stockman LJ, Bellamy R, Garner P. SARS: Systematic review of treatment effects. PLoS Med (2006) 3(9):e343. doi: 10.1371/journal.pmed.0030343

21. Russell CD, Millar JE, Baillie JK. Clinical evidence does not support corticosteroid treatment for 2019-nCoV lung injury. Lancet (2020) 395:473-5. doi: 10.1016/S0140-6736(20)30317-2

22. World Health Organization. Clinical management of when novel coronavirus is suspected: severe acute respiratory infections What to do and what not to do. (2020). Available at: https://www.who.int/publications/i/item/clinicalmanagement-of-covid-19.

23. Lansbury L, Rodrigo C, Leonardi-Bee J, Nguyen-Van-Tam J, Lim WS Corticosteroids as adjunctive therapy in the treatment of influenza. Cochrane Database Syst Rev (2019) 7(3):CD010406. doi: 10.1002/ 14651858.CD010406.pub3

24. World Health Organization. Corticosteroids for COVID-19. (2020). Available at: https://www.who.int/publications/i/item/WHO-2019-nCoVCorticosteroids-2020.1. 
25. Catania A, Gatti S, Colombo G, Lipton JM. Targeting Melanocortin Receptors as a Novel Strategy. Pharmacol Rev (2004) 56(1):1-29. doi: 10.1124/pr.56.1.1.1

26. Catania A, Lonati C, Sordi A, Carlin A, Leonardi P, Gatti S. The melanocortin system in control of inflammation. Scientific World J (2010) 10:1840-53. doi: 10.1100/tsw.2010.173

27. Moscowitz AE, Asif H, Lindenmaier LB, Calzadilla A, Zhang C, Mirsaeidi M. The Importance of Melanocortin Receptors and Their Agonists in Pulmonary Disease. Front Med (2019) 6:145. doi: 10.3389/fmed.2019.00145

28. Wang W, Guo DY, Lin YJ, Tao YX. Melanocortin Regulation of Inflammation. Front Endocrinol (Lausanne) (2019) 10:683. doi: 10.3389/ fendo.2019.00683

29. Teijaro JR. Cytokine storms in infectious diseases. Semin Immunopathol (2017) 39:501-3. doi: 10.1007/s00281-017-0640-2

30. Channappanavar R, Perlman S. Pathogenic human coronavirus infections: causes and consequences of cytokine storm and immunopathology. Semin Immunopathol (2017) 39:529-39. doi: 10.1007/s00281-017-0629-x

31. Fung S-Y, Yuen K-S, Ye Z-W, Chan C-P. Jin D-Y. A tug-of-war between severe acute respiratory syndrome coronavirus 2 and host antiviral defence: lessons from other pathogenic viruses. Emerg Microbes Infect (2020) 9:55870. doi: 10.1080/22221751.2020.1736644

32. Qin C, Zhou L, Hu Z, Zhang S, Yang S, Tao Y, et al. Dysregulation of immune response in patients with COVID-19 in Wuhan, China. Clin Infect Dis (2020) 71(15):762-8. doi: 10.1093/cid/ciaa248

33. Yuen KY, Wong SSY. Human infection by avian influenza A H5N1. Hong Kong Med J (2005) 11(3):189-99.

34. Hiraiwa K, Van Eeden S. Nature and consequences of the systemic inflammatory response induced by lung inflammation. Intech Open (2014). doi: $10.5772 / 57392$

35. Teijaro JR. The role of cytokine responses during influenza virus pathogenesis and potential therapeutic options. Curr Top Microbiol Immunol (2015) 386:3-22. doi: 10.1007/82_2014_411

36. Menachery VD, Eisfeld AJ, Schäfer A, Josset L, Sims AC, Proll S, et al. Pathogenic influenza viruses and coronaviruses utilize similar and contrasting approaches to control interferon-stimulated gene responses. MBio (2014) 5(3):e01174-14. doi: 10.1128/mBio.01174-14

37. Kikkert M. Innate Immune Evasion by Human Respiratory RNA Viruses. J Innate Immun (2020) 12:4-20. doi: 10.1159/000503030

38. Kindler E, Thiel V, Weber F. Interaction of SARS and MERS Coronaviruses with the Antiviral Interferon Response. Adv Virus Res (2016) 96:219-43. doi: 10.1016/bs.aivir.2016.08.006

39. Hale BG, Randall RE, Ortin J, Jackson D. The multifunctional NS1 protein of influenza A viruses. J Gen Virol (2008) 89(Pt 10):2359-76. doi: 10.1099/ vir.0.2008/004606-0

40. DeDiego ML, Nieto-Torres JL, Regla-Nava JA, Jimenez-Guardeno JM, Fernandez-Delgado R, Fett C, et al. Inhibition of NF- B-Mediated Inflammation in Severe Acute Respiratory Syndrome CoronavirusInfected Mice Increases Survival. J Virol (2014) 88:913-24. doi: 10.1128/ jvi.02576-13

41. Siu KL, Yuen KS, Castano-Rodriguez C, Ye ZW, Yeung ML, Fung SY, et al. Severe acute respiratory syndrome Coronavirus ORF3a protein activates the NLRP3 inflammasome by promoting TRAF3-dependent ubiquitination of ASC. FASEB J (2019) 33:8865-77. doi: 10.1096/fj.201802418R

42. Channappanavar R, Fehr AR, Vijay R, Mack M, Zhao J, Meyerholz DK, et al. Dysregulated Type I Interferon and Inflammatory Monocyte-Macrophage Responses Cause Lethal Pneumonia in SARS-CoV-Infected Mice. Cell Host Microbe (2016) 19(2):181-93. doi: 10.1016/j.chom.2016.01.007

43. Henry BM, Vikse J, Benoit S, Favaloro EJ, Lippi G. Hyperinflammation and derangement of renin-angiotensin-aldosterone system in COVID-19: A novel hypothesis for clinically suspected hypercoagulopathy and microvascular immunothrombosis. Clin Chim Acta (2020) 507:167-73. doi: 10.1016/j.cca.2020.04.027

44. Beristain-Covarrubias N, Perez-Toledo M, Thomas MR, Henderson IR, Watson SP, Cunningham AF. Understanding Infection-Induced Thrombosis: Lessons Learned From Animal Models. Front Immunol (2019) 10:2569. doi: 10.3389/fimmu.2019.02569

45. Danthi P. Viruses and the Diversity of Cell Death. Annu Rev Virol (2016) 3 (1):533-53. doi: 10.1146/annurev-virology-110615-042435
46. Hocke AC, Becher A, Knepper J, Peter A, Holland G, Tönnies M, et al. Emerging human middle east respiratory syndrome coronavirus causes widespread infection and alveolar damage in human lungs. Am J Respir Crit Care Med (2013) 188(7):882-6. doi: 10.1164/rccm.201305-0954LE

47. Lampa J, Westman M, Kadetoff D, Agréus AN, Le, Maître E, et al. Peripheral inflammatory disease associated with centrally activated IL-1 system in humans and mice. Proc Natl Acad Sci USA (2012) 109(31):12728-33. doi: $10.1073 /$ pnas. 1118748109

48. Catania A. The melanocortin system in leukocyte biology. J Leukoc Biol (2007) 81(2):383-92. doi: 10.1189/jlb.0706426

49. Gatti S, Lonati C, Sordi A, Catania A. Protective effects of melanocortins in systemic host reactions. Adv Exp Med Biol (2010) 681:117-25. doi: 10.1007/ 978-1-4419-6354-3_9

50. Martin LW, Lipton JM. Acute phase response to endotoxin: Rise in plasma $\alpha-\mathrm{MSH}$ and effects of $\alpha-\mathrm{MSH}$ injection. Am J Physiol - Regul Integr Comp Physiol (1990) 259(4 Pt 2):R768-72. doi: 10.1152/ajpregu.1990.259.4.r768

51. Hernàndez RD, Demitri MT, Carlin $\mathrm{A}$, Meazza $\mathrm{C}$, Villa $\mathrm{P}$, Ghezzi $\mathrm{P}$, et al. Inhibition of systemic inflammation by central action of the neuropeptide $\alpha$ melanocyte-stimulating hormone. Neuroimmunomodulation (1999) 6 (3):187-92. doi: 10.1159/000026381

52. Lonati C, Carlin A, Leonardi P, Valenza F, Bosari S, Catania A, et al. Modulatory effects of NDP-MSH in the regenerating liver after partial hepatectomy in rats. Peptides (2013) 50:142-52. doi: 10.1016/j.peptides.2013.10.014

53. Xu Y, Guan X, Zhou R, Gong R. Melanocortin 5 receptor signaling pathway in health and disease. Cell Mol Life Sci (2020) 77(19):3831-40. doi: 10.1007/ s00018-020-03511-0

54. Abdel-Malek ZA. Melanocortin receptors: Their functions and regulation by physiological agonists and antagonists. Cell Mol Life Sci (2001) 58(3):434-41. doi: 10.1007/PL00000868

55. Voisey J, Carroll L, van Daal A. Melanocortins and their Receptors and Antagonists. Curr Drug Targets (2005) 4(7):586-97. doi: 10.2174/ 1389450033490858

56. Yang Y, Zhang W, Meng L, Yu H, Lu N, Fu G, et al. Alpha-melanocyte stimulating hormone inhibits monocytes adhesion to vascular endothelium. Exp Biol Med (2015) 240(11):1537-42. doi: 10.1177/1535370215581307

57. Rinne P, Ahola-Olli A, Nuutinen S, Koskinen E, Kaipio K, Eerola K, et al. Deficiency in melanocortin 1 receptor signaling predisposes to vascular endothelial dysfunction and increased arterial stiffness in mice and humans. Arterioscler Thromb Vasc Biol (2015) 35(7):1678-86. doi: 10.1161/ ATVBAHA.114.305064

58. Rinne P, Nordlund W, Heinonen I, Penttinen AM, Saraste A, Ruohonen ST, et al. $\alpha$-Melanocyte-stimulating hormone regulates vascular $\mathrm{NO}$ availability and protects against endothelial dysfunction. Cardiovasc Res (2013) 97 (2):360-8. doi: $10.1093 / \mathrm{cvr} / \mathrm{cvs} 335$

59. Vecsernyés M. Protection of cultured brain endothelial cells from cytokineinduced damage by $\alpha$-melanocyte stimulating hormone. Peer J (2018) 6: e4774. doi: $10.7717 /$ peerj. 4774

60. Maaser C, Kannengiesser K, Specht C, Lügering A, Brzoska T, Luger TA, et al. Crucial role of the melanocortin receptor MC1R in experimental colitis. Gut (2006) 55:1415-22. doi: 10.1136/gut.2005.083634

61. Li D, Taylor AW. Diminishment of $\alpha-\mathrm{MSH}$ anti-inflammatory activity in MC1r siRNA-transfected RAW264.7 macrophages. J Leukoc Biol (2008) 84 (1):191-8. doi: 10.1189/jlb.0707463

62. Getting SJ, Perretti M. MC3-R as a novel target for antiinflammatory therapy. Drug News Perspect (2000) 3(1):19-27.

63. Guarini S, Cainazzo MM, Giuliani D, Mioni C, Altavilla D, Marini H, et al. Adrenocorticotropin reverses hemorrhagic shock in anesthetized rats through the rapid activation of a vagal anti-inflammatory pathway. Cardiovasc Res (2004) 63(2):357-65. doi: 10.1016/j.cardiores.2004.03.029

64. Lee DJ, Taylor AW. Following EAU recovery there is an associated MC5rdependent APC induction of regulatory immunity in the spleen. Invest Ophthalmol Vis Sci (2011) 52(12):8862-7. doi: 10.1167/iovs.11-8153

65. Taylor AW, Namba K. In vitro induction of $\mathrm{CD} 25+\mathrm{CD} 4+$ regulatory $\mathrm{T}$ cells by the neuropeptide alpha-melanocyte stimulating hormone $(\alpha-$ MSH). Immunol Cell Biol (2001) 79(4):358-67. doi: 10.1046/j.14401711.2001.01022.x

66. Ericson MD, Lensing CJ, Fleming KA, Schlasner KN, Doering SR, HaskellLuevano C. Bench-top to clinical therapies: A review of melanocortin ligands 
from 1954 to 2016. Biochim Biophys Acta - Mol Basis Dis (2017) 1863:241435. doi: 10.1016/j.bbadis.2017.03.020

67. Sawyer TK, Sanfilippo PJ, Hruby VJ, Engel MH, Heward CB, Burnett JB, et al. 4-Norleucine, 7-d-phenylalanine- $\alpha$-melanocyte-stimulating hormone: A highly potent $\alpha$-melanotropin with ultralong biological activity. Proc Natl Acad Sci USA (1980) 77:5754-8. doi: 10.1073/pnas.77.10.5754

68. Montero-Melendez T, Patel HB, Seed M, Nielsen S, Jonassen TEN, Perretti M. The melanocortin agonist AP214 exerts anti-inflammatory and proresolving properties. Am J Pathol (2011) 179(1):259-69. doi: 10.1016/ j.ajpath.2011.03.042

69. Ying Y, Lan XP, Tian YP. Detection of binding activity and biologic effect of a novel $\beta$-melanocyte-stimulating hormone analogue. Yaoxue Xuebao (2007) 42(3):269-73.

70. Montero-Melendez T. ACTH: The forgotten therapy. Semin Immunol (2015) 27(3):216-26. doi: 10.1016/j.smim.2015.02.003

71. Arnason BG, Berkovich R, Catania A, Lisak RP, Zaidi M. Mechanisms of action of adrenocorticotropic hormone and other melanocortins relevant to the clinical management of patients with multiple sclerosis. Mult Scler J (2013) 19(2):130-6. doi: 10.1177/1352458512458844

72. Askanase A, Li X, Golubovsky J, Hui-Yuen J, Shah U, Olech E, et al. Adrenocorticotropic hormone gel in the treatment of systemic lupus erythematosus: A retrospective study of patients. F1000Research (2015) 4:1103. doi: 10.12688/f1000research.7192.2

73. Herpin TF, Yu G, Carlson KE, Morton GC, Wu X, Kang L, et al. Discovery of tyrosine-based potent and selective melanocortin-1 receptor small-molecule agonists with anti-inflammatory properties. J Med Chem (2003) 46(7):11236. doi: $10.1021 / \mathrm{jm} 025600 \mathrm{i}$

74. Grieco P, Balse PM, Weinberg D, MacNeil T, Hruby VJ. D-amino acid scan of $\gamma$-melanocyte-stimulating hormone: Importance of Trp8 on human MC3 receptor selectivity. J Med Chem (2000) 43(26):4998-5002. doi: 10.1021/ jm000211e

75. Benoit SC, Schwartz MW, Lachey JL, Hagan MM, Rushing PA, Blake KA, et al. A novel selective melanocortin-4 receptor agonist reduces food intake in rats and mice without producing aversive consequences. J Neurosci (2000) 20(9):3442-8. doi: 10.1523/JNEUROSCI.20-09-03442.2000

76. Holder JR, Marques FF, Xiang Z, Bauzo RM, Haskell-Luevano C. Characterization of aliphatic, cyclic, and aromatic N-terminally "capped" His-D-Phe-Arg-Trp-NH2 tetrapeptides at the melanocortin receptors. Eur J Pharmacol (2003) 462(1-3):41-52. doi: 10.1016/S0014-2999(03)01322-0

77. Lipton JM, Ceriani G, Macaluso A, McCoy D, Carnes K, Biltz J, et al. Antiinflammatory effects of the neuropeptide $\alpha-\mathrm{MSH}$ in acute, chronic, and systemic inflammation. Ann N Y Acad Sci (1994) 741:137-48. doi: 10.1111/ j.1749-6632.1994.tb39654.x

78. Getting SJ, Christian HC, Lam CW, Gavins FNE, Flower RJ, Schiöth HB, et al. Redundancy of a Functional Melanocortin 1 Receptor in the Antiinflammatory Actions of Melanocortin Peptides: Studies in the Recessive Yellow (e/e) Mouse Suggest an Important Role for Melanocortin 3 Receptor. J Immunol (2003) 170(6):3323-30. doi: 10.4049/jimmunol.170.6.3323

79. Getting SJ, Di Filippo C, D'Amico M, Perretti M. The melanocortin peptide HP228 displays protective effects in acute models of inflammation and organ damage. Eur J Pharmacol (2006) 532(1-2):138-44. doi: 10.1016/ j.ejphar.2005.12.023

80. Bitto A, Polito F, Altavilla D, Irrera N, Giuliani D, Ottani A, et al. Melanocortins protect against multiple organ dysfunction syndrome in mice. Br J Pharmacol (2011) 162:917-28. doi: 10.1111/j.14765381.2010.01098.x

81. Kristensen J, Jonassen TEN, Rehling M, Tønnesen E, Sloth E, Nielsen S, et al. The Alpha-MSH analogue AP214 attenuates rise in pulmonary pressure and fall in ejection fraction in lipopolysaccharide-induced systemic inflammatory response syndrome in pigs. Clin Physiol Funct Imaging (2011) 31:54-60. doi: 10.1111/j.1475-097X.2010.00979.x

82. Zhu Y, Wu W, Tian Y. Effect of $\alpha$-melanocyte stimulating hormone and its novel analogue on the production of tissue factor pathway inhibitor in mice with endotoxemia. Zhonghua Wei Zhong Bing Ji Jiu Yi Xue (2014) 26 (7):498-502. doi: 10.3760/cma.j.issn.2095-4352.2014.07.011

83. Deng J, Hu X, Yuen PST, Star RA. $\alpha$-Melanocyte-stimulating Hormone Inhibits Lung Injury after Renal Ischemia/Reperfusion. Am J Respir Crit Care Med (2004) 169:749-56. doi: 10.1164/rccm.200303-372oc
84. Giuliani D, Mioni C, Bazzani C, Zaffe D, Botticelli AR, Capolongo S, et al. Selective melanocortin MC 4 receptor agonists reverse haemorrhagic shock and prevent multiple organ damage. Br J Pharmacol (2007) 150:595-603. doi: 10.1038/sj.bjp.0707115

85. Lonati C, Sordi A, Giuliani D, Spaccapelo L, Leonardi P, Carlin A, et al. Molecular changes induced in rat liver by hemorrhage and effects of melanocortin treatment. Anesthesiology (2012) 116(3):692-700. doi: 10.1097/ALN.0b013e318246ea68

86. Sunderkötter C, Kalden H, Brzoska T, Sorg C, Luger TA. $\alpha$-MSH Reduces Vasculitis in the Local Shwartzman Reaction. Ann N Y Acad Sci (2006) 885:414-8. doi: 10.1111/j.1749-6632.1999.tb08701.x

87. Scholzen TE, Sunderkötter C, Kalden DH, Brzoska T, Fastrich M, Fisbeck T, et al. $\alpha$-melanocyte stimulating hormone prevents lipopolysaccharideinduced vasculitis by down-regulating endothelial cell adhesion molecule expression. Endocrinology (2003) 144(1):360-70. doi: 10.1210/en.2002220651

88. Leoni G, Voisin MB, Carlson K, Getting SJ, Nourshargh S, Perretti M. The melanocortin MC 1 receptor agonist BMS-470539 inhibits leucocyte trafficking in the inflamed vasculature. Br J Pharmacol (2010) 160(1):17180. doi: 10.1111/j.1476-5381.2010.00688.x

89. Getting SJ, Riffo-Vasquez Y, Pitchford S, Kaneva M, Grieco P, Page CP, et al. A role for MC3R in modulating lung inflammation. Pulm Pharmacol Ther (2008) 21:866-73. doi: 10.1016/j.pupt.2008.09.004

90. Raap U, Brzoska T, Sohl S, Päth G, Emmel J, Herz U, et al. $\alpha$-MelanocyteStimulating Hormone Inhibits Allergic Airway Inflammation. J Immunol (2003) 171(1):353-9. doi: 10.4049/jimmunol.171.1.353

91. Land SC. Inhibition of cellular and systemic inflammation cues in human bronchial epithelial cells by melanocortin-related peptides: Mechanism of KPV action and a role for MC3R agonists. Int J Physiol Pathophysiol Pharmacol (2012) 4:59-73.

92. Lonati C, Bassani GA, Brambilla D, Leonardi P, Carlin A, Faversani A, et al. Influence of ex vivo perfusion on the biomolecular profile of rat lungs. FASEB J (2018) 32(10):5532-49. doi: 10.1096/fj.201701255R

93. Cannon JG, Tatro JB, Reichlin S, Dinarello CA. $\alpha$ Melanocyte stimulating hormone inhibits immunostimulatory and inflammatory actions of interleukin 1. J Immunol (1986) 137(7):2232-6.

94. Ichiyama T, Okada K, Campbell IL, Furukawa S, Lipton JM. NF- $\kappa B$ activation is inhibited in human pulmonary epithelial cells transfected with $\alpha$-melanocyte-stimulating hormone vector. Peptides (2000) 21:14737. doi: $10.1016 / S 0196-9781(00) 00300-4$

95. Miao YL, Deng XM, Li JB, Zhao XK, Cao JM, Tian YP. Effect of alphamelanocyte stimulating hormone on the apoptosis of the vascular endothelial cell of the lung in two-hit acute respiratory distress syndrome in rat. Zhongguo Wei Zhong Bing Ji Jiu Yi Xue (2004) 16(10):596-8.

96. Jang E, Kim J, Tin TD, Song J, Lee S, Kwak S. The effects of BMS-470539 on lipopolysaccharide- induced acute lung injury. Acute Crit Care (2019) 34:133-40. doi: 10.4266/acc.2019.00507

97. Colombo G, Gatti S, Sordi A, Turcatti F, Carlin A, Rossi C, et al. Production and effects of $\alpha$-melanocyte-stimulating hormone during acute lung injury. Shock (2007) 27(3):326-33. doi: 10.1097/01.shk. $0000239764.80033 .7 \mathrm{e}$

98. Xu PB, Mao YF, Meng HB, Tian YP, Deng XM. STY39, a novel alphamelanocyte-stimulating hormone analogue, attenuates bleomycin-induced pulmonary inflammation and fibrosis in mice. Shock (2011) 35:308-14. doi: 10.1097/SHK.0b013e3181f8f15e

99. Manna SK, Aggarwal BB, Alerts E. $\alpha$-Melanocyte-Stimulating Hormone Inhibits the Nuclear Transcription Factor NF- $\kappa$ B Activation Induced by Various Inflammatory Agents. J Immunol (1998) 161(6):2873-80.

100. Ahmed TJ, Montero-Melendez T, Perretti M, Pitzalis C. Curbing inflammation through endogenous pathways: Focus on melanocortin peptides. Int J Inflam (2013) 2013:985815. doi: 10.1155/2013/985815

101. Catania A, Lonati C, Sordi A, Leonardi P, Carlin A, Gatti S. The peptide NDP-MSH induces phenotype changes in the heart that resemble ischemic preconditioning. Peptides (2010) 31(1):116-22. doi: 10.1016/j.peptides. 2009.09.030

102. Gatti S, Lonati C, Acerbi F, Sordi A, Leonardi P, Carlin A, et al. Protective action of NDP-MSH in experimental subarachnoid hemorrhage. Exp Neurol (2012) 234(1):230-8. doi: 10.1016/j.expneurol.2011.12.039 
103. Bhardwaj RS, Schwarz A, Becher E, Mahnke K, Aragane Y, Schwarz T, et al. Pro-opiomelanocortin-derived peptides induce IL-10 production in human monocytes. J Immunol (1996) 156(7):2517-21.

104. Taylor AW. The immunomodulating neuropeptide alpha-melanocytestimulating hormone $(\alpha-\mathrm{MSH})$ suppresses LPS-stimulated TLR4 with IRAK-M in macrophages. J Neuroimmunol (2005) 162(1-2):43-50. doi: 10.1016/j.jneuroim.2005.01.008

105. Colombo G, Gatti S, Turcatti F, Sordi A, Fassati LR, Bonino F, et al. Gene Expression Profiling Reveals Multiple Protective Influences of the Peptide $\alpha$ Melanocyte-Stimulating Hormone in Experimental Heart Transplantation. J Immunol (2005) 175(5):3391-401. doi: 10.4049/jimmunol.175.5.3391

106. Taylor AW, Lee DJ. The Alpha-Melanocyte Stimulating Hormone Induces Conversion of Effector T Cells into Treg Cells. J Transpl (2011) 2011:246856. doi: $10.1155 / 2011 / 246856$

107. Lee DJ, Taylor AW. Both MC5r and A2Ar Are Required for Protective Regulatory Immunity in the Spleen of Post-Experimental Autoimmune Uveitis in Mice. J Immunol (2013) 191(8):4103-11. doi: 10.4049/jimmunol.1300182

108. Kitaichi N, Namba K, Taylor AW. Inducible immune regulation following autoimmune disease in the immune-privileged eye. J Leukoc Biol (2005) 77 (4):496-502. doi: 10.1189/jlb.0204114

109. Kawanaka N, Taylor AW. Localized retinal neuropeptide regulation of macrophage and microglial cell functionality. J Neuroimmunol (2011) 232 (1-2):17-25. doi: 10.1016/j.jneuroim.2010.09.025

110. Macaluso A, McCoy D, Ceriani G, Watanabe T, Biltz J, Catania A, et al. Antiinflammatory influences of $\alpha$-MSH molecules: Central neurogenic and peripheral actions. J Neurosci (1994) 14(4):2377-82. doi: 10.1523/ jneurosci.14-04-02377.1994

111. Lipton JM, Macaluso A, Hiltz ME, Catania A. Central administration of the peptide $\alpha$-MSH inhibits inflammation in the skin. Peptides (1991) 12 (4):795-8. doi: 10.1016/0196-9781(91)90135-C

112. Getting SJ. Glucocorticoid and Melanocortins: Special Issue. Scientific World $J$ (2007) 7:396054. doi: 10.1100/tsw.2007.93

113. Singh M, Mukhopadhyay K. Alpha-melanocyte stimulating hormone: An emerging anti-inflammatory antimicrobial peptide. BioMed Res Int (2014) 2014:874610. doi: 10.1155/2014/874610

114. Catania A, Cutuli M, Garofalo L, Carlin A, Airaghi L, Barcellini W, et al. The neuropeptide alpha-MSH in host defense. Ann N Y Acad Sci (2000) 917:22731. doi: 10.1111/j.1749-6632.2000.tb05387.x
115. Clemson CM, Yost J, Taylor AW. The Role of Alpha-MSH as a Modulator of Ocular Immunobiology Exemplifies Mechanistic Differences between Melanocortins and Steroids. Ocul Immunol Inflamm (2017) 25(2):179-89. doi: 10.3109/09273948.2015.1092560

116. Taylor AW. Alpha-Melanocyte Stimulating Hormone ( $\alpha-\mathrm{MSH})$ Is a PostCaspase Suppressor of Apoptosis in RAW 264.7 Macrophages. PLoS One (2013) 8(8):e74488. doi: 10.1371/journal.pone.0074488

117. Ottani A, Giuliani D, Galantucci M, Spaccapelo L, Novellino E, Grieco P, et al. Melanocortins counteract inflammatory and apoptotic responses to prolonged myocardial ischemia/reperfusion through a vagus nerve-mediated mechanism. Eur J Pharmacol (2010) 637(1-3):124-30. doi: 10.1016/ j.ejphar.2010.03.052

118. Harris E, Tiganescu A, Tubeuf S, Mackie SL. The prediction and monitoring of toxicity associated with long-term systemic glucocorticoid therapy. Curr Rheumatol Rep (2015) 17(6):513. doi: 10.1007/s11926-015-0513-4

119. Lee TH, Jawan B, Chou WY, Lu CN, Wu CL, Kuo HM, et al. $\alpha$ Melanocyte-stimulating hormone gene therapy reverses carbon tetrachloride induced liver fibrosis in mice. J Gene Med (2006) 8(6):76472. doi: $10.1002 /$ jgm. 899

120. Van Westerloo DJ, Giebelen IAJ, Meijers JCM, Daalhuisen J, de Vos AF, Levi $M$, et al. Vagus nerve stimulation inhibits activation of coagulation and fibrinolysis during endotoxemia in rats. J Thromb Haemost (2006) 4 (9):1997-2002. doi: 10.1111/j.1538-7836.2006.02112.x

121. Leisman DE, Deutschman CS, Legrand M. Facing COVID-19 in the ICU: vascular dysfunction, thrombosis, and dysregulated inflammation. Intensive Care Med (2020) 46(6):1105-8. doi: 10.1007/s00134-02006059-6

Conflict of Interest: The authors declare that the research was conducted in the absence of any commercial or financial relationships that could be construed as a potential conflict of interest.

Copyright $\odot 2020$ Lonati, Gatti and Catania. This is an open-access article distributed under the terms of the Creative Commons Attribution License (CC BY). The use, distribution or reproduction in other forums is permitted, provided the original author(s) and the copyright owner(s) are credited and that the original publication in this journal is cited, in accordance with accepted academic practice. No use, distribution or reproduction is permitted which does not comply with these terms. 